\title{
Erythropoietin Stimulates a Rise in Intracellular Free Calcium Concentration in Single Early Human Erythroid Precursors
}

\author{
Barbara A. Miller, Russell C. Scaduto, Jr., Douglas L. Tillotson, John J. Botti, and Joseph Y. Cheung \\ Departments of Pediatrics, Medicine, Surgery, and Obstetrics and Gynecology, The Milton S. Hershey Medical Center, \\ The Pennsylvania State University, Hershey, Pennsylvania 17033; and the Department of Physiology, \\ Boston University School of Medicine, Boston, Massachusetts 02118
}

\begin{abstract}
Erythropoietin and granulocyte-macrophage colony-stimulating factor (GM-CSF) stimulate the differentiation and proliferation of erythroid cells. To determine the cellular mechanism of action of these growth factors, we measured changes in intracellular free calcium concentration $\left(\left[\mathrm{Ca}_{\mathrm{c}}\right]\right)$ in single human erythroid precursors in response to recombinant erythropoietin and GM-CSF. [Cac] in immature erythroblasts derived from cultured human cord blood erythroid progenitors was measured with fluorescence microscopy digital video imaging. When stimulated with erythropoietin, [Cac] in the majority of erythroblasts increased within $3 \mathrm{~min}$, peaked at $5 \mathrm{~min}$, and returned toward baseline at $10 \mathrm{~min}$. The percentage of cells that responded to erythropoietin stimulation increased in a dose-dependent manner. Additional stimulation with GM-CSF in cells previously exposed to erythropoietin resulted in a second $\left[\mathrm{Ca}_{c}\right]$ increase. Immature erythroblasts treated with GMCSF followed by erythropoietin responded similarly to each factor with a rise in $\left[\mathrm{Ca}_{c}\right]$. The source of transient calcium is intracellular since erythroblasts were incubated in medium devoid of extracellular calcium. Our observations suggest that changes in $\left[\mathrm{Ca}_{\mathrm{c}}\right]$ may be an intracellular signal that mediates the proliferative/differentiating effect of hematopoietic growth factors.
\end{abstract}

\section{Introduction}

The proliferation and differentiation of hematopoietic cells are dependent on the presence of hematopoietic growth factors. Two factors responsible for stimulating erythroid differentiation have recently been identified and cloned: erythropoietin, an obligatory factor required for the proliferation and differentiation of more mature erythroid progenitors and precursors $(1,2)$, and granulocyte-macrophage colony-stimulating factor (GM-CSF), ${ }^{1}$ which stimulates the differentiation of early erythroid progenitors in vitro $(3,4)$. The precise stages of ery-

Address all correspondence to Dr. Barbara A. Miller, Department of Pediatrics, The Milton S. Hershey Medical Center, P.O. Box 850, Hershey, PA 17033.

Received for publication 25 June 1987 and in revised form 7 December 1987.

1. Abbreviations used in this paper: BFU-E, burst-forming unit, erythroid; [Ca $]$ ], intracellular free calcium concentration; GM-CSF, granulocyte-macrophage colony-stimulating factor; $\mathbf{R}$, fluorescence intensity ratio.

J. Clin. Invest.

(c) The American Society for Clinical Investigation, Inc. 0021-9738/88/07/0309/07 \$2.00

Volume 82, July 1988 , 309-315 throid differentiation at which these factors exert their effects, and the cellular mechanism of action are unknown.

The intracellular free calcium concentration $\left[\mathrm{Ca}_{c}\right]$ has been shown to be an intracellular signal for many hormones and growth factors (5-8). Because of the low yield of cells after purification, measurements of $\left[\mathrm{Ca}_{c}\right]$ have been technically difficult to make in erythroid progenitors and early precursors since the fluorescent signals emitted by the small number of fura-2-loaded cells are too low to be detectable by conventional cuvette measurements. Technical difficulties have now been overcome by the development of digital video imaging system by which reliable measurements of $\left[\mathrm{Ca}_{\mathrm{c}}\right]$ or $\mathrm{pH}$ can be made on a single cell.

Here, we report the first measurement of basal $\left[\mathrm{Ca}_{c}\right]$ and its changes in single normal immature erythroid precursors in response to recombinant erythropoietin and GM-CSF.

\section{Methods}

Purification of erythroid progenitor cells. Cord-blood samples were obtained from normal full-term newborn deliveries under a protocol approved by The Milton S. Hershey Medical Center Committee on Clinical Investigation. Cord-blood mononuclear cells were separated on Ficoll-Paque (Pharmacia Inc., Piscataway, NJ) and adherent cells were depleted by adherence to plastic as previously described (9). Nonadherent cells were then labeled for $1 \mathrm{~h}$ at $4^{\circ} \mathrm{C}$ with optimal concentrations of antibodies that recognize myeloid and lymphoid cells to select for antigen-negative stem cells (9). Antibodies included anti-Leu-1, anti-Leu-5b, anti-Leu-9, anti-Leu-10, anti-Leu-12, of Peter Beverly, University College, London, England), and 10 F7 (gift of Dr. William Bigbee, Lawrence Livermore Laboratory, CA). Mononuclear cells were washed and then incubated for $1 \mathrm{~h}$ at $4^{\circ} \mathrm{C}$ on petri dishes coated with affinity purified rabbit anti-mouse IgG, IgA, and IgM. Nonadherent antibody negative cells were removed by swirling plates gently. The frequency of cord-blood burst-forming units erythroid (BFU-E) present in nonadherent cells from this purification step was $1-4 \%$. The final cultured fraction contained $<1 \%$ lymphocytes and $0-5 \%$ monocytes, thus reducing progenitor exposure to factors produced by $\mathrm{T}$ cells and macrophages. Partially purified mononuclear cells from cord blood were cultured in humidified $4 \% \mathrm{CO}_{2}$ at $37^{\circ} \mathrm{C}$ in $0.9 \%$ methycellulose media containing $30 \% \mathrm{FCS}, 9.0 \mathrm{mg} / \mathrm{ml}$ deionized BSA (fraction V; Sigma Chemical Co., St. Louis, MO), $1.4 \times 10^{-4}$ $\mathrm{mol} /$ liter beta-mercaptoethanol, $2 \mathrm{U} / \mathrm{ml}$ erythropoietin (recombinant erythropoietin, > 10,000 U/mg; Amgen, Thousand Oaks, CA), and recombinant GM-CSF (gift of Dr. Steven Clark, Genetics Institute, Cambridge, MA, $25 \mathrm{ng} / \mathrm{ml}$ final concentration) (10). The mass of GM-CSF in transfection-conditioned media was determined by the Genetics Institute (3). Concentrations of erythropoietin and GM-CSF were selected for plateau stimulation of growth $(4,10)$.

Measurement of $\left[\mathrm{Ca}_{c}\right]$ in early erythroid precursor cells. BFU-E derived cells were removed from culture at day 8 , when they were beginning to hemoglobinize. Progenitor (BFU-E)-derived erythroblasts were labeled with plateau concentrations of anti-human $\beta 2$-microglobulin, which recognizes nucleated cells, and then bound to 
anti-mouse Ig-coated glass coverslips by incubating them at $4^{\circ} \mathrm{C}$ for 1 h. The cells were incubated in PBS at $37^{\circ} \mathrm{C}$ for $1 \frac{1}{2} \mathrm{~h}$ with $6 \mu \mathrm{M}$ fura-2 acetoxymethyl ester. Total time lapse from removal of cells from culture to completion of fura-2 loading was 4-6 h. Cells were visualized with the digital imaging system described below, and treated with 0.02 , $0.2,2$, or $10 \mathrm{U} / \mathrm{ml}$ recombinant erythropoietin or $0.25,2.5,25$, or 125 $\mathrm{ng} / \mathrm{ml}$ recombinant GM-CSF after baseline $\left[\mathrm{Ca}_{\mathrm{c}}\right]$ were obtained. For consistency, concentrations of erythropoietin $(2 \mathrm{U} / \mathrm{ml})$ and GM-CSF $(25 \mathrm{ng} / \mathrm{ml})$ identical to those of culture were chosen for time course experiments.

Fura-2 is a fluorescent $\mathrm{Ca}^{2+}$-sensitive probe that can be introduced into cells nondestructively. When chelated with $\mathrm{Ca}^{2+}$, the fluorescence intensity (detected at $510 \mathrm{~nm}$ ) increases when excited at 340 or $350 \mathrm{~nm}$ and decreases when excited at $380 \mathrm{~nm}$ (11). Unlike quin 2 , fura-2 has a low affinity for $\mathrm{Mg}^{2+}$ and its fluorescence is not affected by changes in $\mathrm{pH}$ over the physiological range (11). By quantitating the fluorescence intensity ratio $(R)$ at $350 / 380 \mathrm{~nm}$, small changes in $\left[\mathrm{Ca}_{\mathrm{c}}\right]$ can be detected that are independent of local variations in cell thickness and dye content. Changes in the 350/380 ratio of single cells were detected with a computer-based digital video imaging system.

Our system was constructed using a SPEX dual wavelength fluorimeter as the excitation source. Alternating excitation wavelengths ( 350 and $380 \mathrm{~nm}$ ) were intermittently directed to the objective of a Zeiss IM35 microscope via a dichroic mirror (FT 395; Zeiss, Inc., Thornwood, NY). Cells adherent on coverslips were placed in a DvroakStotler chamber and viewed through Neofluar $63 \times / 1.25$ N.A. objective. Epifluorescence (505 $\pm 20 \mathrm{~nm}$; Ditric Optics Inc., Hudson, MA) was monitored by a charge-coupled device video camera $(3,000 \mathrm{~F}$, Fairchild Industrial Products Co., Winston-Salem, NC) optically coupled to a wafer-type image intensifier (Varo, Inc., Garland, TX) and displayed on-line on a high resolution analog RGB monitor (PVM 1271Q; Sony Corp., Long Island City, NY). Camera output was fed into a digitizing/display board (EPIX SVPC-GRB-1MB) residing in an IBM/AT personal computer. Video data was digitized and displayed at 8 bits/pixel, and 8 video frames ( 256 pixels $\times 480$ lines) were sequentially added to form an accumulated frame (16 bits/pixel) before transfer to system (RAM) memory (6 megabytes). This improves the signal-to-noise ratio of the averaged frame by a factor of $\sqrt{15}$. To permanently store the video data, a Bernoulli $20+20$-megabyte hard disk system (Iomega, Salt Lake City, UT) was used which allows lowcost and high-capacity data storage.

Data were analyzed using custom-written software. Initially, frames of appropriate background fluorescence ( 350 and 380 frames of buffer with no cells) were subtracted pixel by pixel before calculation of $R$. At current sensitivity settings, there was no difference between cell autofluorescence and background fluorescence. The ratioed image was displayed on an RGB monitor, using a pseudocolor (rainbow pattern) code such that red represented the lowest and purple the highest pixel intensity (and hence $\left[\mathrm{Ca}_{\mathrm{c}}\right]$ ). Pictures of the ratioed image were taken with a conventional 35-mm SLR camera (Topcon RE Super) on Kodak color film (ASA 400).

To obtain estimates of $\left[\mathrm{Ca}_{c}\right]$ from $R$, the free acid fura-2 $(5 \mu \mathrm{M})$ was added to a buffer consisting of $120 \mathrm{mM} \mathrm{KCl}, 10 \mathrm{mM} \mathrm{NaCl}, 1 \mathrm{mM}$ $\mathrm{MgCl}_{2}$, and $10 \mathrm{mM}$ Hepes, $\mathrm{pH} 7.05,22^{\circ} \mathrm{C}$. The free $\mathrm{Ca}^{2+}$ concentration of the calibration buffer was adjusted from $<10^{-8} \mathrm{M}$ to $1,500 \mathrm{nM}$ by the addition of EGTA or $\mathrm{Ca}^{2+}(12)$. Paired 350 and 380 images of thin films of the calibration buffer with different free $\mathrm{Ca}^{2+}$ concentrations were obtained and $R$ was calculated.

\section{Results}

Response of immature erythroblasts to erythropoietin. The changes in the fluorescence intensity ratio of individual erythroblasts in response to recombinant erythropoietin are shown in Fig. 1. Fig. $1 A$ shows the baseline ratioed image of a representative group of four immature erythroblasts loaded with fura-2. The same group of immature erythroblasts $3 \mathrm{~min}$ after recombinant erythropoietin treatment $(2 \mathrm{U} / \mathrm{ml})$ is shown in Fig. $1 \mathrm{~B}$. The change from red to yellow-blue color indicates that $\left[\mathrm{Ca}_{c}\right]$ has increased in two of the cells. One other cell is beginning to respond and one did not respond at $3 \mathrm{~min}$, which demonstrates temporally asynchronous responses. $\left[\mathrm{Ca}_{c}\right]$ increased further in all responding cells at $5 \mathrm{~min}$ (Fig. $1 \mathrm{C}$ ). Fig. 1 $D$ shows a decline of $\left[\mathrm{Ca}_{c}\right]$ towards baseline at $10 \mathrm{~min}$ as indicated by a return from blue to red color. To determine if cells previously stimulated by erythropoietin were also capable of responding to GM-CSF, recombinant GM-CSF $(25 \mathrm{ng} / \mathrm{ml})$ was added to the same cells at 10 min posterythropoietin addition. Fig. $1 E$ shows that 3 min post-GM-CSF addition, a second increase in $\left[\mathrm{Ca}_{c}\right]$ occurred in the majority of cells. This increase continued 5 min post-GM-CSF addition (Fig. $1 F$ ). Three experiments from different blood samples were performed with similar results. Of the erythroblasts studied, $57 \%$ responded to both erythropoietin and GM-CSF, $14 \%$ responded to erythropoietin only, and $29 \%$ responded to neither hormone. There was heterogeneity in the amplitude of the response between patients and among cells derived from a single patient.

To quantitate the response to erythropoietin, the mean pixel intensity of the ratioed image of individual responsive erythroblasts before and after addition of growth factors was used for estimates of $\left[\mathrm{Ca}_{c}\right]$ (Methods). Basal $\left[\mathrm{Ca}_{\mathrm{c}}\right]$ was $33 \pm 7$ $\mathrm{nM}$, increased to a peak of $137 \pm 23 \mathrm{nM}$ at $5 \mathrm{~min}$ post $2-\mathrm{U} / \mathrm{ml}$ erythropoietin addition, and decreased to $93 \pm 15 \mathrm{nM}$ at 10 $\min (n=6)$. Further addition of GM-CSF resulted in a second increase in $\left[\mathrm{Ca}_{\mathrm{c}}\right]$ to $163 \pm 13 \mathrm{nM}$.

The ability of immature erythroblasts to respond to different concentrations of erythropoietin with an increase in $\left[\mathrm{Ca}_{c}\right]$ was determined. After stimulation of erythroblasts with 0.02 , $0.2,2$, or $10 \mathrm{U} / \mathrm{ml}$, the mean pixel intensity of the ratioed images $5 \mathrm{~min}$ post stimulation showed a significant increase over baseline at erythropoietin concentration of $0.2 \mathrm{U} / \mathrm{ml}$ or greater (Fig. $2 A ; P<0.05$ by one-way analysis of variance). The percentage of cells that responded to erythropoietin stimulation with an increase in $\left[\mathrm{Ca}_{c}\right]$ was clearly dose-dependent (Fig. $2 \mathrm{~B}$ ). A response was defined as an increase in the mean pixel intensity $\geq 10 \%$ of baseline, since cells treated with mock Cos-cell supernatant had $<10 \%$ change over baseline during 10 min of observation.

Extracellular calcium was not necessary for the observed $\left[\mathrm{Ca}_{c}\right]$ increase since cells were superfused with PBS devoid of
Figure 1. Fluorescence intensity ratio $(350 / 380)$ in four single progenitor-derived erythroblasts stimulated with erythropoietin followed by GM-CSF. $(A)$ Baseline; $(B) 3 \mathrm{~min}$ post erythropoietin $(2 \mathrm{U} / \mathrm{ml})$ addition; $(C) 5$ min posterythropoietin addition; $(D) 10$ min post erythropoietin addition; $(E) 13$ min post erythropoietin addition and 3 min post GM-CSF addition; $(F) 15$ min post erythropoietin and 5 min post GM-CSF addition. Pixel intensity of the ratioed image and hence of $\left[\mathrm{Ca}_{\mathrm{c}}\right]$ are quantitated and displayed at 256 discrete levels (gray scale). Pseudocoloring with a continuous rainbow pattern (red, lowest $\left[\mathrm{Ca}_{c}\right]$; purple, highest $\left.\left[\mathrm{Ca}_{c}\right]\right)$ enhances the visual presentation of changes in $\left[\mathrm{Ca}_{c}\right]$. 

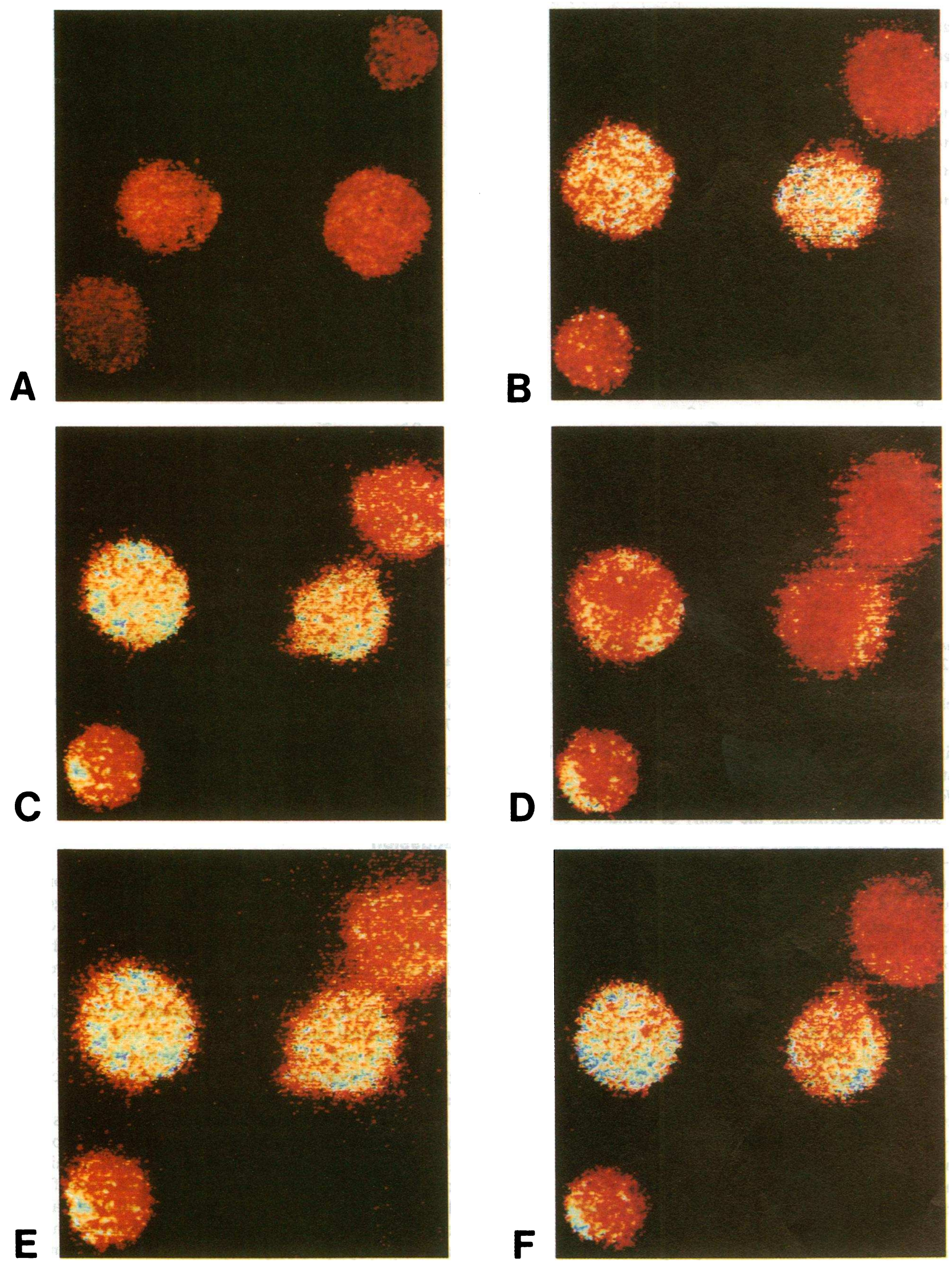

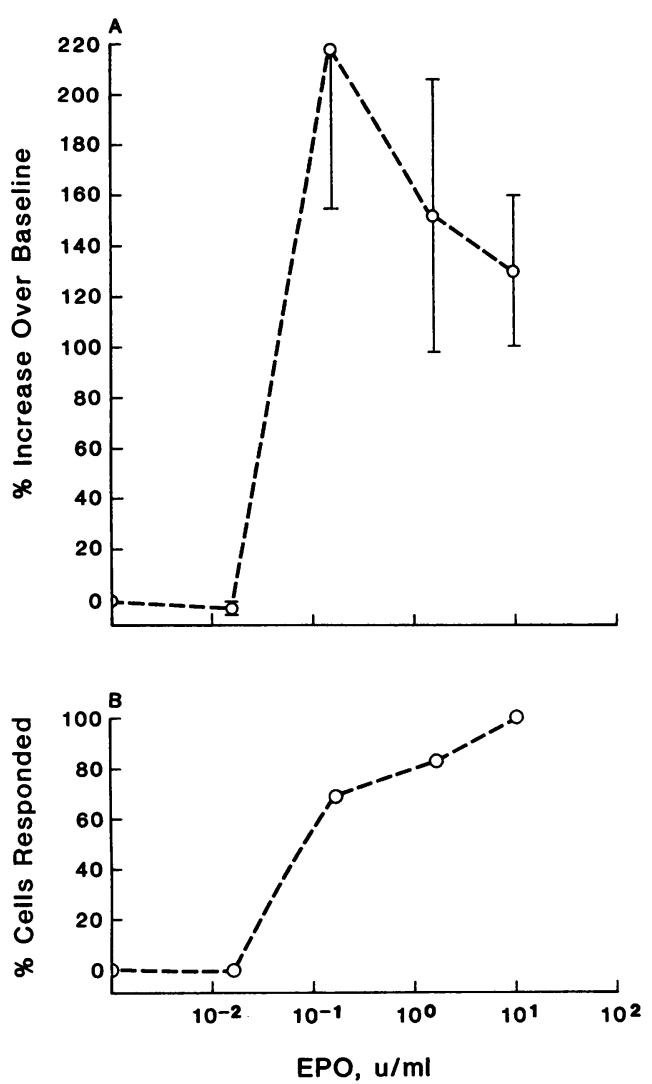

Figure 2. Response of day 8 BFU-E-derived erythroblasts to 0.02 , $0.2,2$, or $10 \mathrm{U} / \mathrm{ml}$ recombinant erythropoietin. $(A)$ Mean $\pm \mathrm{SE}$ of percent increase of fluorescence ratio over baseline and $(B)$ percentage of cells that responded at each concentration.

calcium. This observation suggests that the source of calcium must have been derived from intracellular stores.

Response of immature erythroblasts to GM-CSF. In a second series of experiments, the ability of immature erythroblasts to respond to different concentrations of recombinant GM-CSF with changes in [ $\left.\mathrm{Ca}_{\mathrm{c}}\right]$ was determined. Results after stimulation with $0.25,2.5,25$, or $125 \mathrm{ng} / \mathrm{ml} \mathrm{GM-CSF}$ are shown in Fig. 3. 5 min after GM-CSF addition, a significant increase in free intracellular calcium was observed with 25 and $125 \mathrm{ng} / \mathrm{ml} \mathrm{GM}$-CSF compared with 0.25 and $2.5 \mathrm{ng} / \mathrm{ml}$ (Fig. 3 $A, P<0.002)$. The percentage of cells that responded was dose-dependent and approached plateau at $25-125 \mathrm{ng} / \mathrm{ml}$ (Fig. 3 B).

Changes in the fluorescence intensity ratio of day 8 BFU-E-derived erythroblasts in response to $25 \mathrm{ng} / \mathrm{ml}$ recombinant GM-CSF are shown in Fig. 4. Fig. $4 A$ shows the baseline ratioed image of four cells treated in one representative experiment. In three of these cells $\left[\mathrm{Ca}_{c}\right]$ increased at $5 \mathrm{~min}$ after stimulation with GM-CSF (Fig. $4 \mathrm{~B}$ ). Similar to the responses of cells to erythropoietin stimulation, their $\left[\mathrm{Ca}_{c}\right]$ responses to GM-CSF addition were temporally asynchronous. In the responsive cells, $\left[\mathrm{Ca}_{c}\right]$ returned toward baseline at $\mathbf{1 0}$ min (Fig. $4 \mathrm{C}$ ). Stimulation at $10 \mathrm{~min}$ with erythropoietin (2 $\mathrm{U} / \mathrm{ml}$ ) resulted in a second rise in $\left[\mathrm{Ca}_{\mathrm{c}}\right]$ in two of the cells within 1-3 min (Fig. $4 \mathrm{D}$ ). Three experiments were performed with similar results.

In this series of experiments, basal $\left[\mathrm{Ca}_{\mathrm{c}}\right]$ was $70 \pm 18 \mathrm{nM}$. Addition of $25 \mathrm{ng} / \mathrm{ml} \mathrm{GM}-\mathrm{CSF}$ increased $\left[\mathrm{Ca}_{\mathrm{c}}\right]$ to $167 \pm 26 \mathrm{nM}$

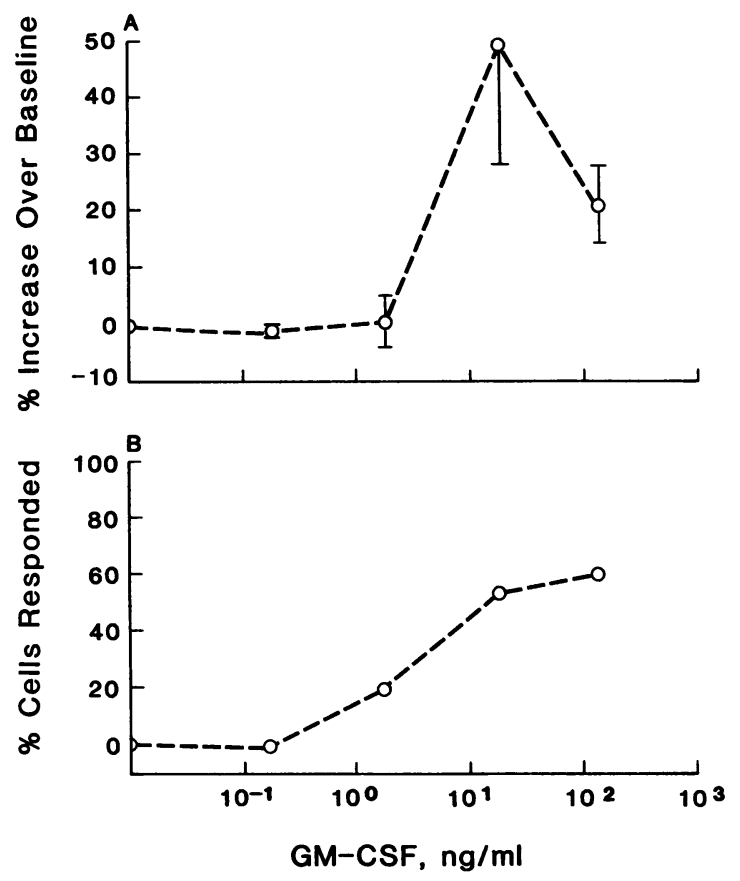

Figure 3. Response of day 8 BFU-E-derived erythroblasts to 0.25 , $2.5,25$, or $125 \mathrm{ng} / \mathrm{ml}$ recombinant GM-CSF. $(A)$ Mean \pm SE of percent increase of fluorescence ratio over baseline and $(B)$ percentage of cells that responded at each concentration.

by $5 \min (n=5)$ in those cells that responded. Elevation of $\left[\mathrm{Ca}_{\mathrm{c}}\right]$ was not sustained but declined to $145 \pm 46 \mathrm{nM}$ at $10 \mathrm{~min}$ post-GM-CSF addition. Further addition of erythropoietin to GM-CSF-treated cells resulted in a second rise of $\left[\mathrm{Ca}_{c}\right]$ to $247 \pm 98 \mathrm{nM}$.

Two control groups of cells treated with mock Cos-cell supernatant (inactive) showed no change in $\left[\mathrm{Ca}_{\mathrm{c}}\right]$ after $10 \mathrm{~min}$ of observation.

\section{Discussion}

Erythropoietin is an obligatory factor required for the proliferation and differentiation of more mature erythroid progenitors (CFU-E) (2, 13-15) and stimulates the proliferation of proerythroblasts and basophilic erythroblasts (16). Whether the earliest committed erythroid progenitor (BFU-E) can respond to erythropoietin is uncertain. GM-CSF has GM-CSA, burstpromoting activity for BFU-E, and stimulates colonies derived from multipotent (mixed) progenitors in vitro $(3,4)$. Both erythropoietin and GM-CSF are important biologically since both have activity in vivo $(17,18)$. The mechanism of action of these growth factors, however, remains unknown.

Previous work suggests involvement of ionic fluxes in the regulation of cell growth and differentiation (5-7). In particular, a transient rise in $\left[\mathrm{Ca}_{c}\right]$ was observed in sea urchin eggs undergoing division (8) as well as during anaphase of $\mathrm{Pt} \mathrm{K}_{1}$ cells (19). Studies in normal and leukemia cell lines have implicated a role for intracellular $\mathrm{Ca}^{2+}$ in the mechanism of action of erythropoietin. Erythropoietin-induced murine erythroid colony growth was enhanced by the ionophore A23187 but inhibited by treatment with EGTA, a nonspecific chelator of $\mathrm{Ca}^{2+}(20)$. Other indirect evidence implicating $\left[\mathrm{Ca}_{c}\right]$ in control of erythroid cell growth and differentiation include $(a)$ the 

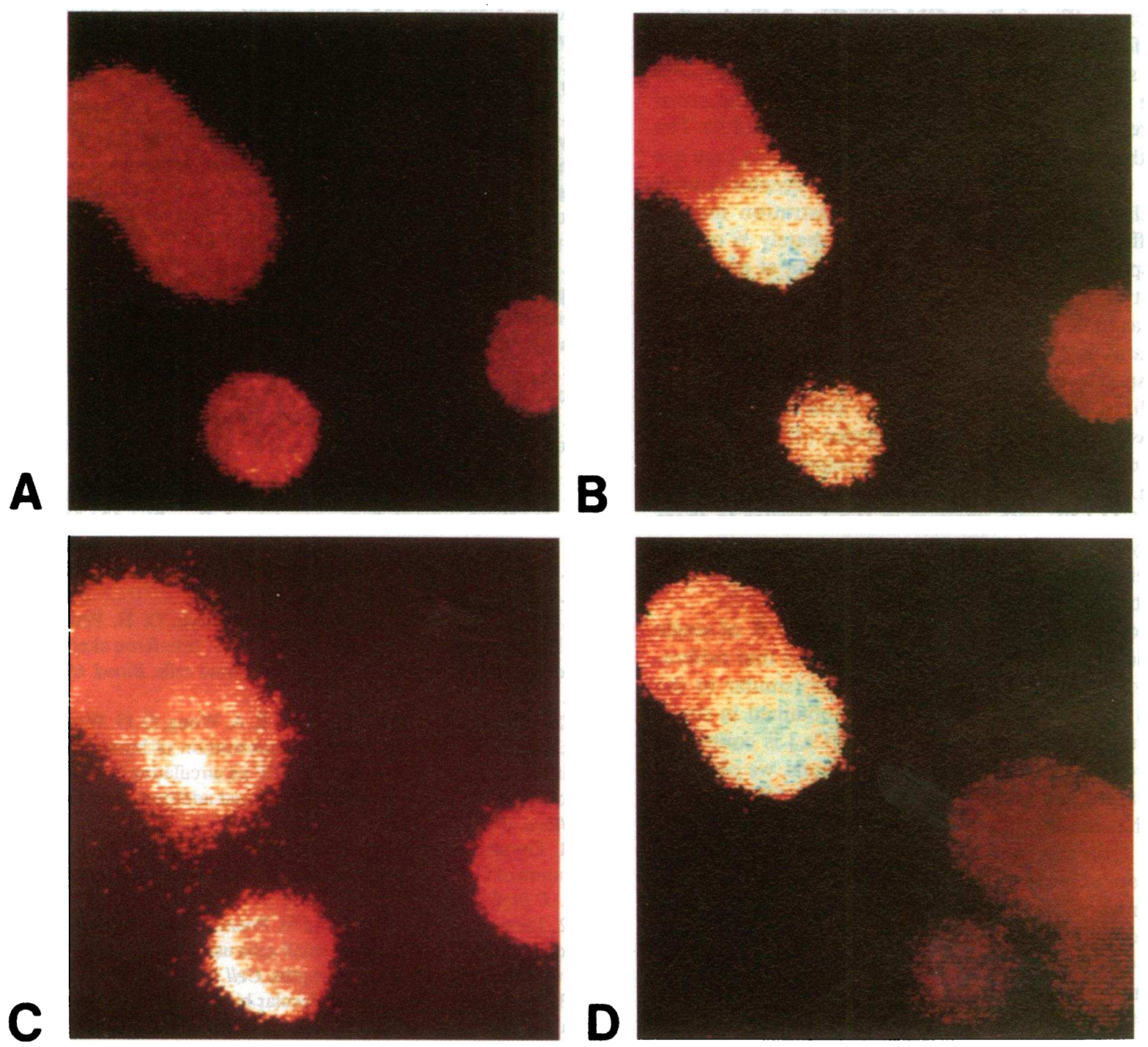

Figure 4. Fluorescence intensity ratio (350/380) in four single progenitor-derived erythroblasts stimulated with GM-CSF, followed by erythropoietin. $(A)$ Baseline; $(B) 5 \mathrm{~min}$ post GM-CSF addition; $(C) 10 \mathrm{~min}$ post GM-CSF treatment; and $(D) 13$ min post GM-CSF and 3 min post erythropoietin treatment. Pseudocoloring code is identical to Fig. 1.

demonstration that an increase in $\mathrm{Ca}^{2+}$ influx is an early necessary step in the commitment to maturation of murine erythroleukemia cells (21); and (b) erythropoietin treatment of Friend virus-infected erythroid cells results in rapid changes in transmembrane $\mathrm{Ca}^{2+}$ flux (22). Using flow cytometry, Mladenovic and Kay have also demonstrated an increase in intracellular free calcium in a select population of normal bone marrow mononuclear cells and membrane depolarization of benzidine-positive nucleated marrow cells in response to erythropoietin $(23,24)$. Our current study clearly demonstrates that a transient rise in $\left[\mathrm{Ca}_{\mathrm{c}}\right]$ occurs rapidly in early erythroid precursors exposed to erythropoietin or GM-CSF. Taken together, our data, as well as previous observations (20-24), strongly suggest that elevation in $\left[\mathrm{Ca}_{c}\right]$ is an intracellular signal that mediates the effect of these hematopoietic growth factors.

The source of cytosolic $\mathrm{Ca}^{2+}$ increase is most likely derived from intracellular sources since our experiments were deliberately conducted in the absence of extracellular $\mathrm{Ca}^{2+}$. In analogy with many other $\mathrm{Ca}^{2+}$-dependent hormones, a unifying hypothesis is that hematopoietic growth factors, on binding to their receptors, stimulate membrane phosphoinositide turnover with a resultant increase in $\left[\mathrm{Ca}_{c}\right]$ from intracellular stores and cytoplasmic alkalinization (25-28). The relative importance of intracellular $\mathrm{Ca}^{2+}$ and $\mathrm{pH}$ signals in promoting cell division and differentiation is at present poorly understood.

Our current observations demonstrate temporal heterogeneity in $\left[\mathrm{Ca}_{\mathrm{c}}\right]$ responses to growth factor stimulation (Fig. 1, B, $C$, and $D$ ). Despite the fact that our progenitor-derived precursors are relatively homogeneous in stage of differentiation and basal $\left[\mathrm{Ca}_{c}\right]$, the time to peak $\left[\mathrm{Ca}_{c}\right]$ increase was clearly different among cells of the same preparation. This temporal asynchrony as well as variability in absolute amplitude of $\left[\mathrm{Ca}_{c}\right]$ changes in response to growth factors among single cells may be responsible for the large standard errors in $\left[\mathrm{Ca}_{c}\right]$ changes in the dose-response relationships of erythropoietin or GM-CSF (Figs. $2 A$ and $3 A$ ). Nevertheless, a dose-dependent response to growth factor stimulation clearly exists since the percentage of cells that elevate $\left[\mathrm{Ca}_{c}\right]$ increase with increasing concentrations 
of erythropoietin (Fig. $2 B$ ) or GM-CSF (Fig. $3 B$ ). Another unexpected feature revealed by digital imaging is the possible presence of spatial heterogeneity of $\left[\mathrm{Ca}_{c}\right]$ in responsive cells (blue-purple vs. red-orange pseudocoloration can be discerned in different regions of cells in Figs. $1, B$ and $C, 4, B$ and $D$ ). The reasons for the spatial-temporal heterogeneity in $\left[\mathrm{Ca}_{c}\right]$ are not obvious but may be related to differences in receptor density and intracellular $\mathrm{Ca}^{2+}$ mobilization/sequestration mechanisms in different regions of cells. Approximately $1 / 3$ of cells failed to respond to either growth factor except at extremely high concentrations of erythropoietin. These cells were judged to be viable as indicated by trypan blue exclusion and by their ability to maintain $\left[\mathrm{Ca}_{c}\right]$ at resting levels. The reasons for the failure of response in these cells are presently unknown.

The ability of erythroid progenitors cells to respond to GM-CSF has been previously demonstrated (4), but the precise stage of differentiation at which cells respond to GM-CSF is unknown. Here, unexpectedly, erythroid precursors responded to GM-CSF with changes in $\left[\mathrm{Ca}_{c}\right]$ similar to those seen with erythropoietin. This observation demonstrates that erythroid cells can interact directly with GM-CSF at later stages of maturation than previously recognized.

Calculation of $\left[\mathrm{Ca}_{c}\right]$ from fluorescence ratio $\mathrm{R}$ of single cells is problematic. Williams et al. (29) showed that calibration curves obtained in calibrating solutions (similar to the ones used in this study) are close to those obtained in single amphibian smooth muscle cells in which $\left[\mathrm{Ca}_{\mathrm{c}}\right]$ is controlled with ionomycin. Using our calibrating solutions, we obtained basal $\left[\mathrm{Ca}_{c}\right]$ values in erythroblasts of $60 \pm 9 \mathrm{nM}(n=24)$. We wish to emphasize that this value represents the lower boundary of $\left[\mathrm{Ca}_{c}\right]$ estimates since recent observations on fura-2loaded human polymorphonuclear leukocytes indicate the presence of intracellular $\mathrm{Ca}^{2+}$-insensitive forms of fura-2 (30). Interference of fluorescence measurements (mostly at $380 \mathrm{~nm}$ ) by the $\mathrm{Ca}^{2+}$-insensitive fura- 2 species will have the net effect of underestimating $\left[\mathrm{Ca}_{c}\right]$ as well as artifactually attenuating the magnitude of $\left[\mathrm{Ca}_{c}\right]$ transients. However, these caveats do not detract from the major conclusion of our study, which is that erythropoietic growth factors induce a transient increase in $\left[\mathrm{Ca}_{c}\right]$ in erythroblasts.

In summary, this observation is the first measurement of free intracellular calcium in single normal erythroblasts. The data demonstrate that early erythroid precursors respond to hematopoietic growth factors with changes in intracellular free calcium concentration.

\section{Acknowledgments}

B. A. Miller is the recipient of National Heart, Lung, and Blood Institute Clinical Investigator Award KO8-HLO1947. R. C. Scaduto, Jr., is the recipient of National Institutes of Health National Research Service Award AM-07317. D. L. Tillotson was supported in part by a research grant from the Whitaker Foundation. J. Y. Cheung is the recipient of the American Heart Association Clinician-Scientist Award 84-429, a Whitaker Foundation research grant, an American Heart Association (Pennsylvania Affiliate) grant-in-aid, and a Juvenile Diabetes Foundation research grant.

\section{References}

1. Jacobs, K., C. Shoemaker, R. Rudersdorf, S. D. Neill, R. J. Kaufman, M. Mufson, J. Sukra, S. S. Jones, R. Hewick, E. F. Fritsch, M. Kawakita, T. Shimizu, and T. Miyake. 1985. Isolation and charac- terization of genomic and cDNA clones of human erythropoietin. Nature (Lond.). 313:806-810.

2. Spivack, J. 1986. The mechanism of action of erythropoietin. Int. J. Cell Cloning. 4:139-166.

3. Wong, G. G., J. S. Witck, P. A. Temple, K. M. Wilkens, A. C. Leary, D. P. Luxenberg, S. S. Jones, E. L. Brown, R. M. Kay, E. C. Orr, C. Shoemaker, D. W. Golde, R. J. Kaufman, R. M. Hewick, E. A. Wang, and S. C. Clark. 1985. Human GM-CSF: molecular cloning of the complementary DNA and purification of the natural and recombinant proteins. Science (Wash. DC). 228:810-815.

4. Sieff, S. A., S. G. Emerson, R. E. Donahue, D. G. Nathan, E. A. Wang, G. G. Wong, and S. C. Clark. 1985. Human recombinant granulocyte-macrophage colony-stimulating factor: a multi-lineage hematopoietin. Science (Wash. DC). 230:1171-1173.

5. Zglinicki, T. 1986. The second messenger system in the stimulation of cellular growth. Acta Histochem. 33(Suppl.):309-315.

6. Pelzelt, C., and S. deNollin. 1986. Regulation of compartmentalization of intracellular calcium ions. Prog. Clin. Biol. Res. 209A:315324.

7. Moolenaar, W. H., L. H. K. Defize, and S. W. de Laat. 1986. Ionic signaling by growth factor receptors. J. Exp. Biol. 124:359-373.

8. Poenie, M., A. Alderston, R. Y. Tsien, and R. A. Steinhordt. 1985. Changes of free calcium levels with stages of the cell division cycle. Nature (Lond.). 315:147-149.

9. Miller, B. A., S. P. Perrine, G. Antognetti, D. H. Perlmutter, S. G. Emerson, C. Sieff, and D. V. Faller. 1987. Interferon alters globin gene expression in neonatal and adult erythroid cells. Blood. 69:16741681.

10. Donahue, R. E., S. G. Emerson, E. A. Wong, G. G. Wong, S. C. Clark, and D. G. Nathan. 1985. Demonstration of burst-promoting activity of recombinant human GM-CSF on circulating erythroid progenitors using an assay involving the delayed addition of erythropoietin. Blood. 66:1479-1481.

11. Grynkiewicz, G., M. Poenie, and R. Y. Tsien. 1985. A new generation of $\mathrm{Ca}^{2+}$ indicators with greatly improved fluorescence properties. J. Biol. Chem. 260:3440-3450.

12. Tsien, R. Y., T. J. Rink, and M. Poenie. 1985. Measurement of cytosolic free $\mathrm{Ca}^{2+}$ in individual small cells using fluorescence microscopy with dual excitation wave lengths. Cell Calcium. 6:145-157.

13. Metcalf, D. 1986. The molecular biology and functions of the granulocyte macrophage colony-stimulating factors. Blood. 67:257267.

14. Papayannopoulou, T., and C. A. Finch. 1972. On the in vivo action of erythropoietin: a quantitative analysis. J. Clin. Invest. 51:1179-1185.

15. Stephenson, J. R., A. A. Axelrod, D. L. McLeod, and M. M. Shreeve. 1971. Induction of colonies of hemoglobin-synthesizing cells by erythropoietin in vitro. Proc. Natl. Acad. Sci. USA. 68:1542-1546.

16. Glass, J., L. M. Lavidor, and S. H. Robinson. 1975. Use of cell separation and short term culture techniques to study erythroid cell development. Blood. 46:705-711.

17. Eschbach, J. W., J. C. Egrie, M. R. Downing, J. K. Browne, and J. W. Adamson. 1987. Correction of the anemia of end-stage renal disease with recombinant human erythropoietin. N. Engl. J. Med. 316:73-78.

18. Donahue, R. E., E. A. Wong, D. K. Stone, R. Kamen, G. G. Wong, P. K. Sehgal, D. G. Nathan, and S. C. Clark. 1986. Stimulation of hematopoiesis in primates by continuous infusion of recombinant human GM-CSF. Nature (Lond.). 321:872-875.

19. Poenie, M., A. Alderton, R. Steinhardt, and R. Tsien. 1986. Calcium rises abruptly and briefly throughout the cell at the onset of anaphase. Science (Wash. DC). 233:886-889.

20. Misiti, J., and J. L. Spivak. 1979. Erythropoiesis in vitro. Role of calcium. J. Clin. Invest. 64:1573-1579.

21. Levenson, R., D. Houseman, and L. Cantley. 1980. Amelioride inhibits murine erythroleukemia cell differentiation: evidence for a calcium requirement for commitment. Proc. Natl. Acad. Sci. USA. 77:5948-5952. 
22. Sawyer, S. T., and S. B. Krantz. 1984. Erythropoietin stimulates ${ }^{45} \mathrm{Ca}^{2+}$ uptake in Friend virus-infected erythroid cells. J. Biol. Chem. 259:2769-2774.

23. Mladenovic, J., E. D. Zanjani, and N. E. Kay. 1986. Erythropoietin stimulates cytoplasmic calcium flux in bone marrow cells Clin. Res. 34:465a. (Abstr.)

24. Mladenovic, J., and N. E. Kay. 1986. Delineation of erythropoietin induced early activation signals in human bone marrow mononuclear cells. Blood. 68:172a. (Abstr.)

25. Berridge, M. J., and R. F. Irvine. 1984. Inositol trisphosphate, a novel second messenger in cellular signal transduction. Nature (Lond.). 312:315-321.

26. Morgan, J. I., and T. Curran. 1986. Role of ion flux in the control of c-fos expression. Nature (Lond.). 322:552-557.
27. Berridge, M. J. 1987. Inositol lipids and cell proliferation. Biochim. Biophys. Acta. 907:33-45.

28. Muldoon, L. L., R. J. Dinerstein, and M. L. Villereal. 1985. Intracellular pH in human fibroblasts: effect of mitogens, A23187, and phospholipase activation. Am. J. Physiol. 249(Cell Physiol 18):C140C148.

29. Williams, D. A., K. E. Fogarty, R. Y. Tsien, and F. S. Fay. 1985. Calcium gradients in single smooth muscle cells revealed by the digital imaging microscope using Fura-2. Nature (Lond.). 318:558561.

30. Scanlon, M., D. A. Williams, and F. S. Fay. 1987. A Ca ${ }^{2+}$-insensitive form of Fura-2 associated with polymorphonuclear leukocytes. J. Biol. Chem. 262:6308-6312. 